УДК 623.396

${ }^{1}$ Лев Миколайович Сакович (канд. техн. наук, доцент)

${ }^{1}$ Вадим Петрович Романенко (канд. техн. наук)

${ }^{1}$ Сергій Свгенович Гнатюк (канд. техн. наук)

${ }^{2}$ Ігор Юрійович Розум (канд. військ. наук, стариий науковий співробітник)

\author{
${ }^{1}$ Національний технічний університет Украӥни “Киӥвський політехнічний інститут імені Ігоря \\ Сікорського”, Київ, Украӥна \\ ${ }^{2}$ Національний університет оборони Украӥни імені Івана Черняховського, Киӥв, Украӥна
}

\title{
КОМПЛЕКСНІСТЬ ПІДХОДУ ДО ОЦІНЮВАННЯ ЕФЕКТИВНОСТІ ФУНКЦІОНУВАННЯ СИСТЕМИ ЗВ’ЯЗКУ ЗА ВІДПОВІДНИМИ ПОКАЗНИКАМИ ЯКОСТІ
}

\begin{abstract}
Підвищення ефективності функиіонування систем зв'язку в сучасних умовах їх розвитку є однією з актуальних науково-практичних проблем. Особлива увага у вирішенні иіієі проблеми приділяється питанням кількісного оцінювання ефективності функціонування зазначених систем, причому не за окремими показниками, а комплексно з врахуванням впливу всіх показників якості на результат використання системи за призначенням. Публікація має за мету формалізачію процесу комплексної очінки ефективності системи зв'язку та показати на прикладі дотримання вимог до надійності та готовності можливість упорядкування дій щодо ії оцінки $з$ розрахунком імовірнісних показників якості.

Оиінка ефективності системи зв'язку - багатокритеріальна задача визначення реального стану різноманітних складових якості ї функціонування. Запропоновано формалізацію комплексної оцінки ефективності з урахуванням впливу на ї̈ значення окремих показників якості. Наукова новизна роботи полягає у кількісній оцінці значення імовірнісних показників окремих складових і комплексного оцінювання якості функціонування системи зв'язку в цілому. Отримані результати доцільно використовувати як під час оцінки ефективності існуючих, так $i$ при обгрунтованому виборі варіанту розвитку перспективних систем зв'язку.
\end{abstract}

Ключові слова: система зв'язку, комплексна оцінка ефективності функціонування системи

\section{Вступ}

Ведення сучасних бойових дій стає все більш складними. Це пов'язано, перш за все, $з$ істотно зміненими засобами збройної боротьби, способами їх застосування i, як наслідок, тактики ведення сучасних бойових дій. Сучасні бойові дії стають все більш інтенсивним в умовах тактичної обстановки, що постійно змінюється. У таких умовах органам військового управління вкрай складно прийняти обгрунтоване рішення на ведення бойових дій, на що вказує і досвід ведення бойових дій у ході ведення антитерористичної операції на Сході нашої країни. В умовах сьогодення начальник зв'язку не має інструментарію, який міг б надати йому допомогу у процесі прийняття рішення.

Постановка проблеми. Підвищення ефективності функціонування систем зв'язку (С3) в сучасних умовах ï розвитку є однією з актуальних науково-практичних проблем. Особлива увага у вирішенні цієї проблеми приділяється питанням кількісного оцінювання ефективності функціонування зазначених систем, причому не за окремими показниками, а комплексно 3 врахуванням впливу всіх показників якості на результат використання системи за призначенням.

Аналіз остатніх досліджень і публікацій. Останніми роками проводяться наукові дослідження щодо кількісної оцінки якості дотримання окремих вимог до використання за призначенням С3. В [1] сформульовані принципи побудови сучасних С3 та визначені вимоги до них, але відсутні рекомендації щодо кількісної оцінки показників якості. В [2-5] визначені перспективні напрямки розвитку С3 3 урахуванням досвіду передових країн світу. В [6-10] приведено рекомендації щодо оцінки надійності окремих зразків техніки зв'язку (Т3), а також надійності і живучості С3 в цілому. В [11-16] розглянуті питання удосконалення діагностичного, а в $[17,18]$ метрологічного забезпечення ремонту ТЗ. Проте, попередні дослідження не мали системного характеру, а вирішували часткові завдання. Аналіз робіт, присвячених методам оцінювання ефективності С3 показує, що далеко не всі вони знаходять широке практичне застосування, не завжди є оптимальними, не враховують специфіку експлуатації Т3 у реальних умовах.

Мета статті: Формалізувати процес комплексної оцінки ефективності С3 та показати на прикладі дотримання вимог до надійності та готовності можливість упорядкування дій щодо іï оцінки 3 розрахунком імовірнісних показників якості.

\section{Виклад основного матеріалу} дослідження.

Система зв'язку - сукупність взаємопов'язаних, сумісних та узгоджених за завданнями підсистем, яка задовольняе вимогам [1]:

висока готовність до використання за призначенням - здатність СЗ в любий час та в любих обставинах виконувати задачі по забезпеченню обміну 
інформацією між користувачами;

стійкість - здатність С3 виконувати завдання за призначенням за умов впливу всіх вражаючих факторів (характеризується живучістю, завадостійкістю та надійністю С3);

мобільність - здатність С3 в установлені строки розгортатися в установлені терміни, змінювати топологію та можливості відповідно до умов обстановки;

пропускна спроможність - здатність С3 забезпечувати обслуговування потоків інформації за одиницю часу з заданою якістю;

безпека - здатність СЗ і автоматизації забезпечувати захист від несанкціонованого доступу та імітостійкість;

функціональна сумісність - здатність С3 забезпечувати сумісну роботу засобів електрозв'язку і автоматизації з іншими системами без додаткових пристроїв спряження та додаткового програмного забезпечення.
У дійсний час відсутня єдина методика комплексної оцінки задоволення вказаних вимог до С3, що затрудняє можливість оцінити ефективність існуючих та обгрунтувати вибір раціонального варіанту їх подальшого розвитку.

Найбільш доступно кількісно оцінити відповідність С3 вимогам щодо надійності, готовності, мобільності і пропускної спроможності при наявності встановлених керівними документами критеріїв, але по мірі розвитку систем зв'язку також необхідно їх наукове обгрунтування [6-10].

Рішення задачі комплексної оцінки ефективності С3 доцільно виконувати в наступній послідовності (рис. 1):

в результаті збору та аналізу вихідних даних визначити фактори, що впливають на показники якості C3 та установити функціональні залежності значення цих показників від керованих змінних для отримання нормованих значень кількісної оцінки дотримання вимог $\left(\Pi_{\mathrm{i}}\right)$;
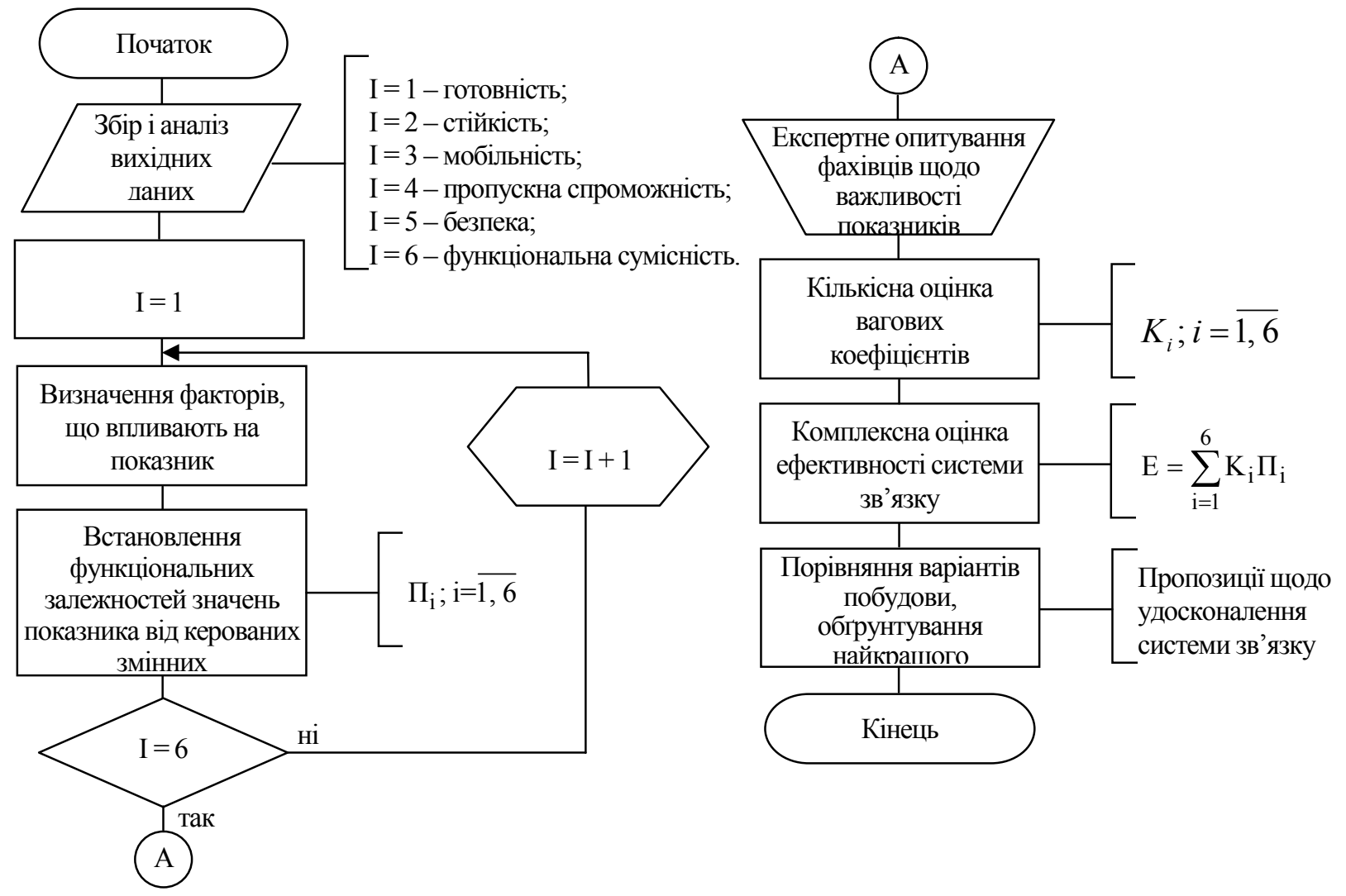

Рис. 1. Блок-схема алгоритму комплексної оцінки ефективності системи зв'язку

експертним опитуванням провідних фахівців 3 організації зв'язку кількісно оцінити вагові коефіцієнти всіх показників якості С3 $\left(\mathrm{K}_{\mathrm{i}}\right)$;

виконати комплексну оцінку ефективності С3 у вигляді кількісної оцінки ймовірності іiі відповідності вимогам $0<\mathrm{E}=\sum_{\mathrm{i}=1}^{6} \mathrm{~K}_{\mathrm{i}} \Pi_{\mathrm{i}} \leq 1$, де $0 \leq \Pi_{\mathrm{i}} \leq 1 ; 0<\mathrm{K}_{\mathrm{i}}<1 ; \sum_{\mathrm{i}=1}^{6} \mathrm{~K}_{\mathrm{i}}=1$,

в результаті ранжування за ступенем зменшення значення Е визначити найбільш перспективні варіанти розвитку $\mathrm{C} 3$.

Одним із найважливіших показників якості С3 $\epsilon$ надійність, без якої їх використання втрачає сенс. Розглянемо можливість формалізованої оцінки цієї вимоги щодо С3.

Властивість надійності С3 полягає у спроможності забезпечити зв'язок зі збереженням у часі встановлених вимогами значень експлуатаційних показників, що підтримуються підсистемою технічного забезпечення зв’язку з виконанням усіх видів ремонту ТЗ, технічного обслуговування та забезпечення експлуатаційновитратними матеріалами. 
Традиційно, як основний показник надійності С3 використовується коефіцієнт готовності $\mathrm{A}_{\mathrm{C}}$ [19], який являє собою імовірність технічної справності усіх засобів ТЗ і готовності до функціонування в повному обсязі усіх напрямків зв'язку. Однак, для С3 більш об'єктивною характеристикою $\epsilon$ імовірність технічної готовності системи до обміну інформацією між абонентами хоча б по одному напрямку зв'язку $\mathrm{P}_{\mathrm{C}}$, що у літературі 3 теорії надійності визначається як імовірність зв'язності чи ймовірність справного стану хоча б одного з можливих напрямків зв'язку:

$$
\mathrm{P}_{\mathrm{c}}=1-\prod_{\mathrm{j}=1}^{\mathrm{S}}\left(1-\mathrm{A}_{\mathrm{j}}\right),
$$

де $\mathrm{A}_{\mathrm{j}}$ - коефіцієнт готовності j-го напрямку зв'язку, $\mathrm{S}$ кількість напрямків зв'язку між абонентами в С3.

Цей вираз кількісно оцінює верхню межу мережевої надійності, а значення нижньої межі розраховують згідно [20] за виразом:

$$
P_{\mathrm{cH}}=\prod_{j=1}^{S}\left(1-U_{j}\right)=\prod_{j=1}^{S} A_{j},
$$

де $\mathrm{U}_{\mathrm{j}}=1-\mathrm{A}_{\mathrm{j}}-$ коефіцієнт неготовності j-го напрямку зв'язку.

Для спрощення розрахунків використовують наближені методи оцінювання Езарі-Прошана i Поліського, які зводяться до розгляду неповних подій зв'язності та не зв'язності, що визначаються нижніми оцінками [19].

Об'єктивна оцінка якості С3 повинна враховувати крім ймовірності зв'язності також значення “ерлангових” втрат р, зумовлених зайнятістю каналів за час $\mathrm{t}$ виконання задачі передачі повідомлення. Тоді комплексний показник надійності напрямку зв'язку приймає вигляд [21]:

$$
\mathrm{W}_{\mathrm{j}}=1-\prod_{\mathrm{j}=1}^{\mathrm{S}}\left[1-\mathrm{A}_{\mathrm{j}}\left(1-\mathrm{p}_{\mathrm{j}}\right) \exp \left(-\frac{\mathrm{t}}{\mathrm{T}_{\mathrm{j}}}\right)\right],
$$

де $\mathrm{T}_{\mathrm{j}}$ - напрацювання на відмову Т3 що утворює шлях j.

Вочевидь, що $\mathrm{W}_{\mathrm{j}}<\mathrm{P}_{\mathrm{c}}$, тому що $\mathrm{Ð}_{\tilde{n}}$ кількісно оцінює потенційну структурну надійність С3. Звідси випливає, що при комутації каналів доцільно використовувати як критерій вибору шляху показник [21]:

$$
\mathrm{V}_{\mathrm{j}}=\frac{\mathrm{W}_{\mathrm{j}}}{\mathrm{r}_{\mathrm{j}}} ; \mathrm{j}=\overline{1, \mathrm{~m}} ;
$$

де $r_{j}$ - кількість переприйомів напрямку зв'язку j iз m можливих.

Напрямки зв'язку вибирають в міру зменшення значення цього показника і перевага завжди віддається більш надійним, найменш завантаженим 3 мінімальною кількістю переприйомів, що дозволяє підвищити ефективність управління топологією С3 [22].

В такому разі в якості нормованого показника надійності С3 доцільно використовувати значення $\mathrm{P}_{\mathrm{c}}$, яке отримують за блок-схемою рис. 2 після аналізу топології С3, складу їі Т3 та вимог до мінімального припустимого значення імовірності зв'язності $\mathrm{P}_{\mathrm{cn}}$, де $\mathrm{n}_{\mathrm{j}}$ - кількість ТЗ напрямку ј. Тобто, нормоване значення стійкості кількісно дорівнює $\Pi_{2}=\mathrm{P}_{\text {c }}$.

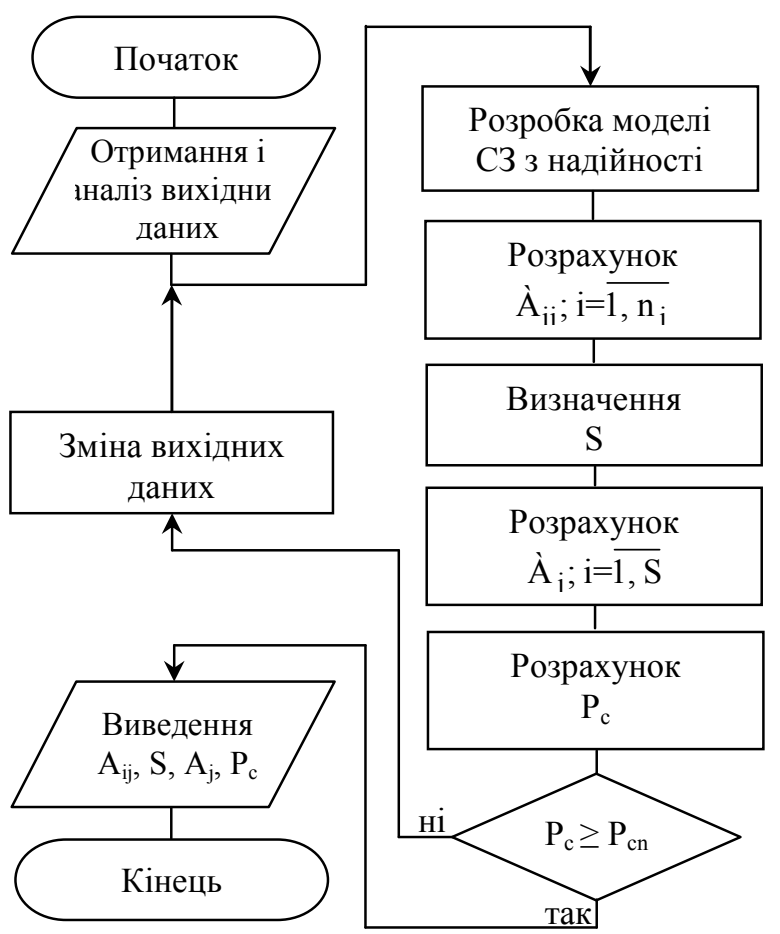

Рис. 2. Блок-схема алгоритму розрахунку імовірності зв'язності системи зв'язку

Розглянемо можливість формалізації кількісної оцінки значення однієї з основних вимог до С3 готовності до використання, яка залежить від професійної підготовки персоналу, технічного стану ТЗ, технічного, діагностичного та метрологічного забезпечення. Це можливо кількісно оцінити під час контролю технічного забезпечення зв'язку 3 метою глибокого і всебічного вивчення стану ТЗ та організації роботи персоналу з експлуатаціі.

Послідовність дій першого етапу формалізовано у вигляді граф-схеми рис. 3, а перелік відповідних операцій приведено в таблиці 1, де враховано фактори, що впливають на готовність окремих зразків ТЗ.

Комплексна оцінка готовності С3 є багато кроковим процесом:

на першому етапі кількісно оцінюють технічний стан окремих зразків Т3;

потім отримують кількісну оцінку технічного стану апаратних зв'язку (АЗ), яка враховує фактори, що впливають на якість готовності;

далі оцінюють технічний стан і готовність до використання за призначенням групи однотипної техніки вузла зв'язку;

на завершальному етапі отримують комплексну оцінку готовності вузла зв'язку залежно від його призначення.

Граф-схема представлення процесу оцінки стану Т3 (рис. 3) дозволяє 3 використанням математичного апарату алгебри логіки розглянути можливі варіанти оцінки технічного стану: 


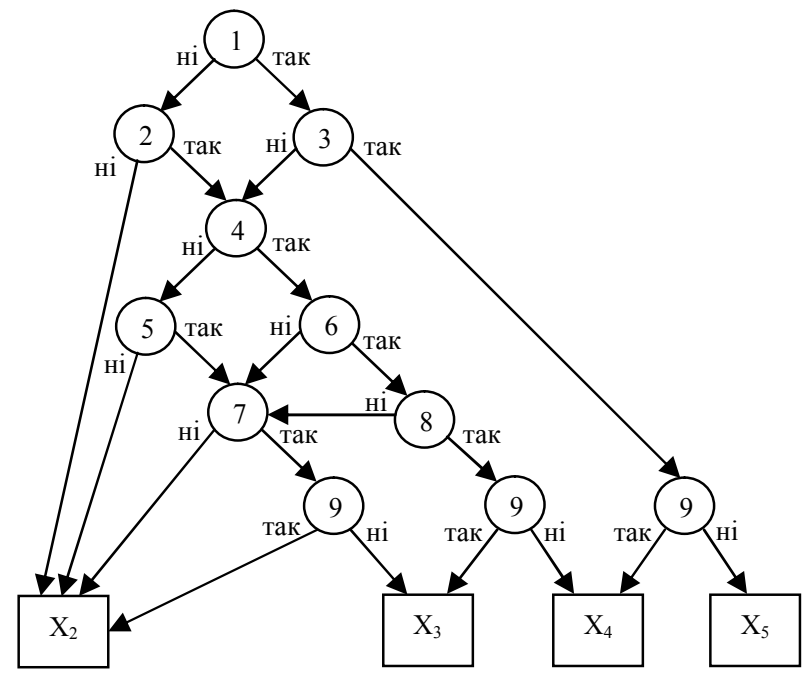

Рис. 3. Граф-схема алгоритму операцій оцінки технічного стану зразків засобів зв'язку

Таблиця 1

Перелік операцій оцінки технічного стану зразків засобів зв'язку

\begin{tabular}{|c|c|}
\hline \begin{tabular}{|c|} 
Умов- \\
ний \\
номер \\
\end{tabular} & Зміст операції \\
\hline 1 & $\begin{array}{l}\text { Зразок справний, ЗІП-0 укомплектований, } \\
\text { документація ведеться правильно, засоби } \\
\text { електробезпеки справні. }\end{array}$ \\
\hline 2 & $\begin{array}{l}\text { Зразок працездатний, укомплектований } \\
\text { складовими частинами, готовий до } \\
\text { використання. }\end{array}$ \\
\hline 3 & $\begin{array}{c}\text { Своєчасно і якісно в повному обсязі } \\
\text { проведено чергове технічне обслуговування. }\end{array}$ \\
\hline 4 & $\begin{array}{l}\text { Комплектність ЗІП-0 не менше } 50 \% \\
\text { кожної номенклатури i } \\
\text { менше } 85 \% \text {. }\end{array}$ \\
\hline 5 & $\begin{array}{l}\text { Комплектність ЗІП-0 не менше } 50 \% \\
\text { кожної номенклатури i } \\
\text { менше } 75 \% \text {. }\end{array}$ \\
\hline 6 & $\begin{array}{l}\text { Значення параметрів доведенні до норм } \\
\text { екіпажем за допомогою регулювання в } \\
\text { процесі перевірки зразка. }\end{array}$ \\
\hline 7 & $\begin{array}{l}\text { Виявлені недоліки усунені екіпажем із } \\
\text { залученням фахівців ремонтного органу і } \\
\text { використанням ЗІП-0 не пізніше } 4 \text { годин. }\end{array}$ \\
\hline 8 & $\begin{array}{c}\text { Виявлені недоліки усунені екіпажем } \\
\text { використанням ЗІП-0 не пізніше } 1 \text { години. }\end{array}$ \\
\hline 9 & 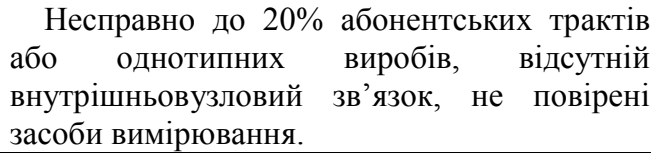 \\
\hline
\end{tabular}

$X=X_{5} \vee X_{4} \vee X_{3} \vee X_{2}=\underset{i=2}{\vee} X_{i}$

$\mathrm{X}_{5}=\mathrm{x}_{1} \mathrm{x}_{3} \overline{\mathrm{x}_{9}}$

$\mathrm{X}_{4}=\mathrm{x}_{1} \mathrm{x}_{3} \mathrm{x}_{9} \vee \mathrm{x}_{1} \overline{\mathrm{x}_{3}} \mathrm{x}_{4} \mathrm{x}_{6} \mathrm{x}_{8} \overline{\mathrm{x}_{9}} \vee \overline{\mathrm{x}_{1}} \mathrm{x}_{2} \mathrm{x}_{4} \mathrm{x}_{6} \mathrm{x}_{8} \overline{\mathrm{x}_{9}}$;

$\mathrm{X}_{3}=\mathrm{x}_{1} \overline{\mathrm{x}_{3}} \mathrm{x}_{4} \mathrm{x}_{6} \mathrm{x}_{8} \mathrm{x}_{9} \vee \overline{\mathrm{x}_{1}} \mathrm{x}_{2} \mathrm{x}_{4} \mathrm{x}_{6} \mathrm{x}_{8} \mathrm{x}_{9} \vee \overline{\mathrm{x}_{1}} \mathrm{x}_{2} \mathrm{x}_{4} \overline{\mathrm{x}_{6}} \mathrm{x}_{7} \overline{\mathrm{x}_{9}} \vee$

$\overline{v \mathrm{x}_{1}} \mathrm{x}_{2} \mathrm{x}_{4} \mathrm{x}_{6} \mathrm{x}_{7} \overline{\mathrm{x}_{8} \mathrm{x}_{9}} \vee \overline{\mathrm{x}_{1}} \mathrm{x}_{2} \overline{\mathrm{x}_{4}} \mathrm{x}_{5} \mathrm{x}_{7} \overline{\mathrm{x}_{9}}$;
$\mathrm{X}_{2}=\overline{\mathrm{x}_{1} \mathrm{x}_{2}} \vee \overline{\mathrm{x}_{1}} \mathrm{x}_{2} \overline{\mathrm{x}_{4} \mathrm{x}_{5}} \vee \overline{\mathrm{x}_{1}} \mathrm{x}_{2} \overline{\mathrm{x}_{4}} \mathrm{x}_{5} \overline{\mathrm{x}_{7}} \vee \overline{\mathrm{x}_{1}} \mathrm{x}_{2} \overline{\mathrm{x}_{4}} \mathrm{x}_{5} \mathrm{x}_{7} \mathrm{x}_{9} \vee$

$\vee \overline{x_{1}} x_{2} x_{4} x_{6} \overline{x_{7} x_{8}} \vee \overline{x_{1}} x_{2} x_{4} x_{6} x_{7} \overline{x_{8}} x_{9}$;

де $\mathrm{X}$ - технічний стан T3;

$\mathrm{X}_{\mathrm{i}}$ - оцінка технічного стану $(\mathrm{i}=\overline{2,5})$;

$\mathrm{x}_{\mathrm{i}}$ - позитивна оцінка операції $i$ таблиці 1 ;

$\overline{\mathrm{x}_{\mathrm{i}}}$ - негативна оцінка операції $i$ таблиці 1 .

Це необхідно для кількісної оцінки показників якості процесу визначення стану ТЗ.

Розглянемо можливість кількісної оцінки математичного сподівання (МС) відхилення оцінки технічного стану зразку ТЗ від дійсного при наявності однієї помилки у визначенні результату виконання операції таблиці 1 на прикладі оцінки “добре”. Згідно [23] МС дискретної величини дорівнює сумі добутку значення випадкової величини на ймовірність ㄲï появи.

В такому разі отримуємо:

помилка на першому кроці не впливає на результат;

помилка на другому кроці (операція 2) дає найбільше відхилення оцінки стану Т3, яке дорівнює 2(1-p)p;

помилка на інших кроках приводять до відхилення оцінки стану Т3 на (1-p) $\mathrm{p}^{5}$;

де $\mathrm{p}$ - імовірність правильної оцінки результату виконання операції таблиці 1 .

Аналогічно отримаємо МС відхилення оцінки для всіх можливих випадків за умови, що ймовірності правильної оцінки результатів виконання всіх операцій однакові і дорівнюють $\mathrm{p}$ :

$$
\begin{aligned}
& \rho_{2}=2(1-p) p^{2}+2(1-p) p^{5}=2(1-p) p^{2}\left(1+p^{3}\right) \\
& \rho_{3}=(1-p) p^{5}+(1-p) p^{5}+(1-p) p^{5}+ \\
& +(1-p) p^{5}+(1-p) p^{5}=5(1-p) p^{5} \\
& \rho_{4}=2(1-p) p+(1-p) p^{5}+(1-p) p^{5}+ \\
& +(1-p) p^{5}=\left(2+3 p^{4}\right)(1-p) p \\
& \rho_{5}=(1-p) p^{5}+(1-p) p^{4}+(1-p) p^{2}= \\
& =\left[p^{2}(p+1)+1\right](1-p) p^{2}
\end{aligned}
$$

Мінімальне значення імовірності правильної оцінки стану Т3 отримуємо при максимальній кількості перевірок:

$$
\mathrm{P}_{5}=\mathrm{p}^{3} ; \mathrm{P}_{4}=\mathrm{p}^{6} ; \mathrm{P}_{3}=\mathrm{P}_{2}=\mathrm{p}^{7} \text {. }
$$

5.

Отримані результати відображено на рис. $4 \mathrm{i}$

Розглянемо вимоги до значення р за умов

$\mathrm{P} \geq 0,9$ i $\mathrm{p} \leq 0,5[21,24]:$ 


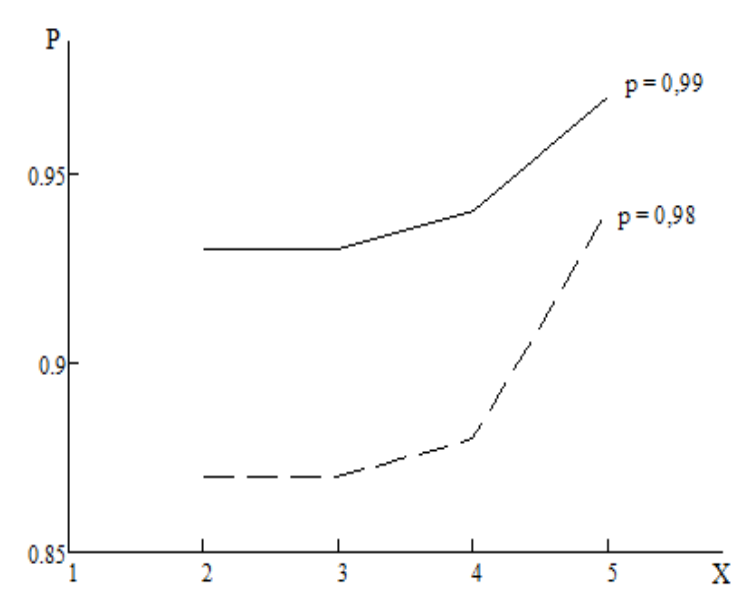

Рис. 4. Залежності мінімального значення імовірності правильної оцінки стану зразків засобів спеціального зв'язку

$$
\rho_{4}=\left(2+3 p^{4}\right)(1-p) p \leq 0,5-\text { рішення існує при }
$$
$\mathrm{p} \geq 0,8$;

$$
\mathrm{P}_{3}=\mathrm{p}^{7} \geq 0,9 \text { - рішення існує при } \mathrm{p} \geq 0,988 \text {. }
$$

Виконання операцій таблиці 1 потребує одночасного оцінювання кількох логічних умов. Відомо, що ймовірність прийняття правильного рішення при декількох логічних умовах дорівнює [24]:

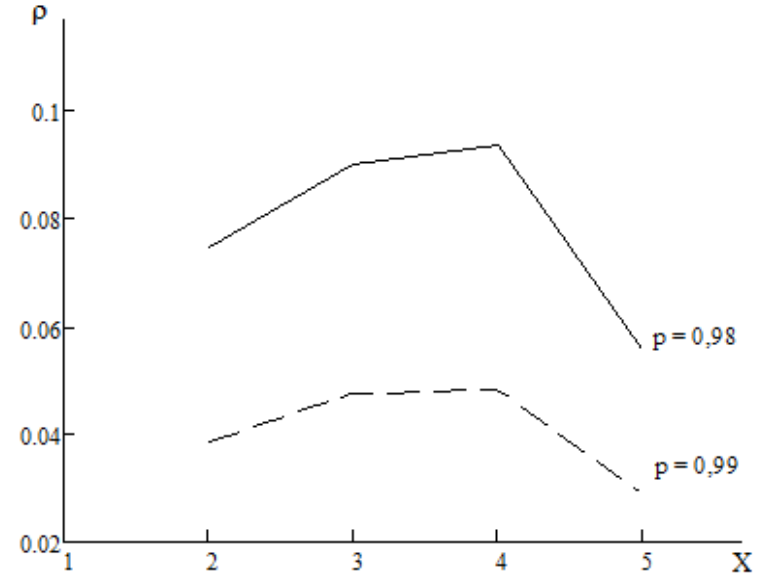

Рис. 5. Залежності математичного сподівання відхилення оцінки стану зразків засобів спеціального зв'язку

$$
\begin{array}{ll}
\text { одне, два } & \mathrm{p}=0,995 ; \\
\text { три, чотири } & \mathrm{p}=0,950 ; \\
\text { п'ять і більше } & \mathrm{p}=0,900 ;
\end{array}
$$

що відповідає отриманим результатам.

Використання отриманих результатів щодо оцінки технічного стану окремих зразків Т3, підготовки персоналу, технічного і метрологічного забезпечення їx експлуатації дозволяє формалізувати процес оцінки технічного стану АЗ в цілому (рис. 6).
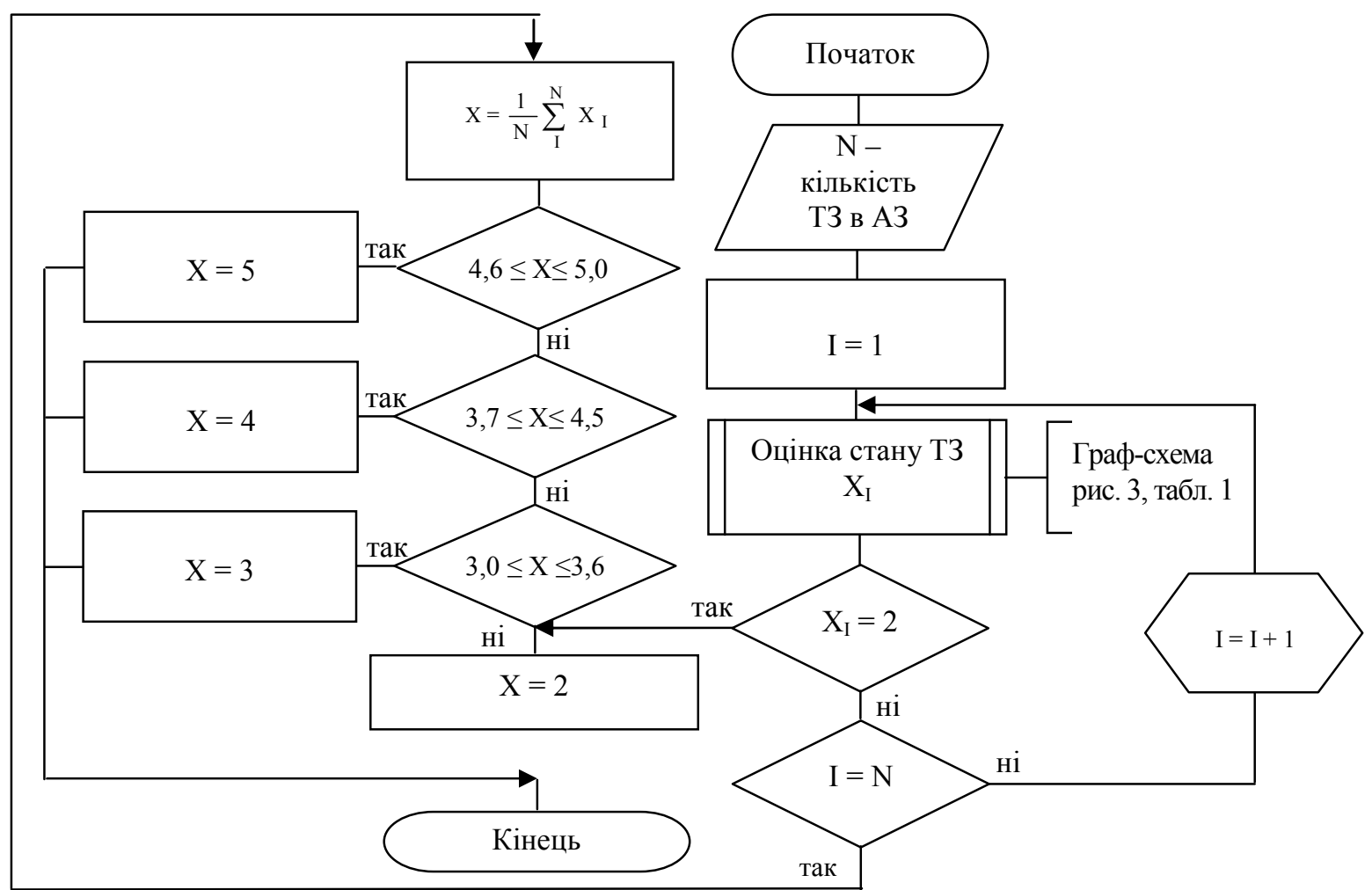

Рис. 6. Блок-схема алгоритму оцінки технічного стану апаратної зв'язку

Оцінка технічного стану окремих АЗ дозволяє в подальшому оцінити технічний стан групи однотипної техніки. Вся Т3 підрозділяється на $\mathrm{n}$ груп, порядок оцінки стану яких приведено на рис. 7, де $\mathrm{n}_{\mathrm{i}}-$ кількість перевірених АЗ, що отримали оцінку $\mathrm{X}_{\mathrm{i}}=\overline{2,5} ; \mathrm{N}-$ загальна кількість зразків техніки в групі; $Z_{\mathrm{i}}$ - відсоток АЗ що отримали оцінку i; Z - загальна оцінка групи однотипних засобів зв'язку.

На завершальному етапі оцінки готовності вузла зв'язку враховують кількість справної та працездатної T3, що отримала позитивні оцінки $(\mathrm{Z}>2)$ за групами. 
При оцінці готовності С3 доцільно їх порівняти за отриманим значенням $\eta_{\mathrm{o}}$, яке в подальшому дорівнює

Згідно вимог вузол зв'язку $\epsilon$ готовим до використання, якщо відношення справної та працездатної Т3 до їх штатної кількості для основних груп $\eta_{\mathrm{o}} \geq 0,75$ і для не основних груп $\eta_{\mathrm{H}} \geq 0,5$.
$\Pi_{1}$ згідно рис. 1, а нерівність $\eta_{\mu} \geq 0,5$, використовувати як обмеження.

Таким чином, приведений в роботі підхід дозволяє об'єктивно і комплексно оцінити ступінь готовності вузлів зв’язку під час перевірки.

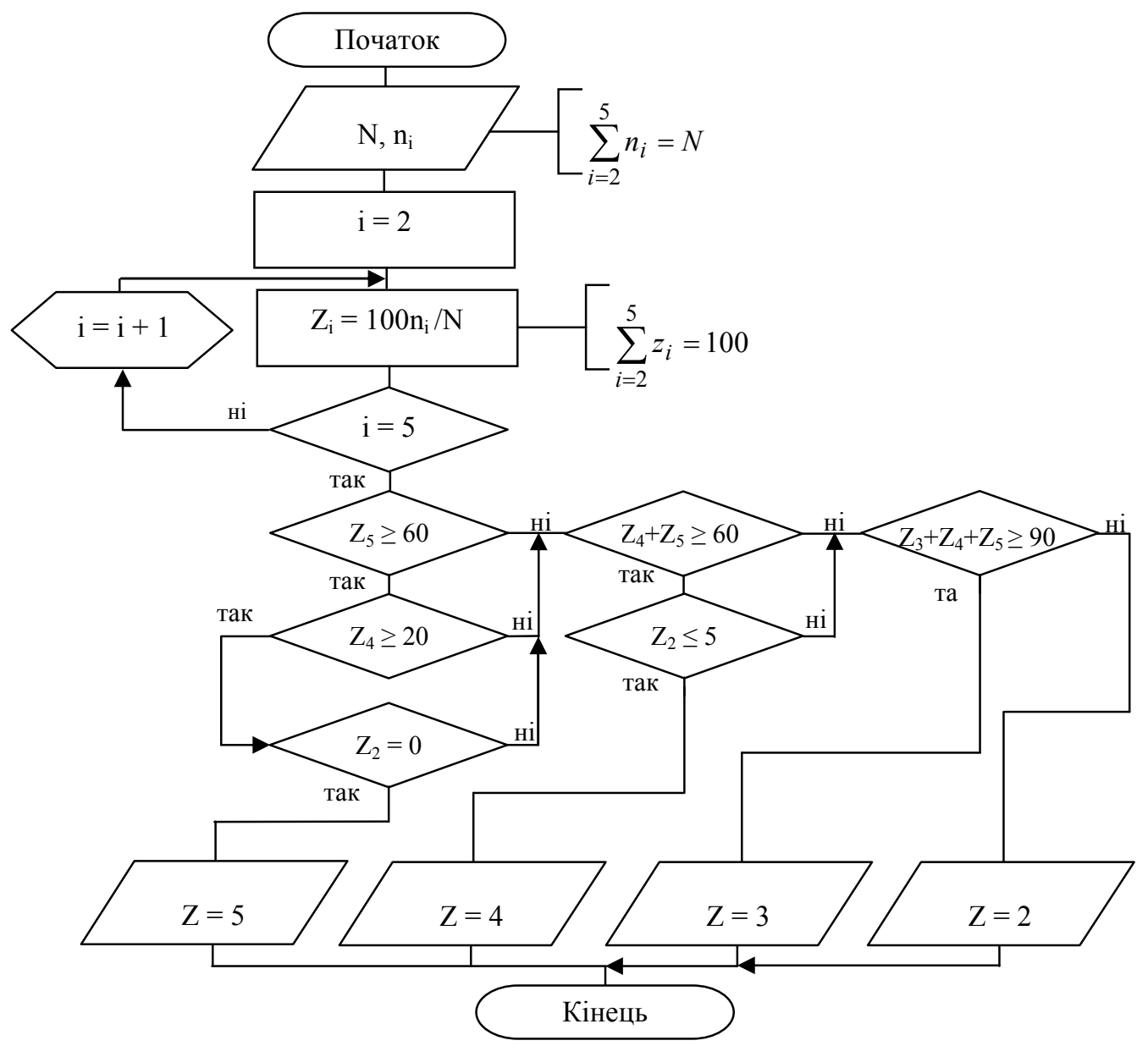

Рис. 7. Блок-схема алгоритму оцінки технічного стану груп однотипних засобів зв'язку

\section{Висновки й перспективи подалыших досліджень.}

В статті на основі проведеного аналізу відомих методів оцінювання ефективності С3 з врахуванням вимог керівних документів формалізований порядок дій під час перевірки задоволення дійсним вимогам.

На прикладі кількісної оцінки надійності та готовності С3 вперше розглянуто можливість реалізації запропонованих етапів оцінки 3 визначенням ймовірнісних показників отриманих результатів, в чому

\section{Jimepamypa}

1. Олійник В.Ф. Основи теорії систем зв'язку. - К: Техніка, 2000. - 152 с. 2. Edward Golan, Adam Kraśniewski, Janusz Romanik, Paweł Skarżyński, Robert Urban, "Experimental Performance Evaluationof the Narrowband VHF Tactical IP Radioin Test-Bed Environment", Military Communications and Information Technology: A Trusted Cooperation Enabler, vol. 2. pp. 99-106, 2012. 3. United States. Joint Chiefs of Staff, Defense Technical Information Center (DTIC). Joint Publication 6-0: Joint Communications System (2015, June 10). [Online]. Available: ttp://www.dtic.mil/doctrine/new_pubs/jp6_0.pdf. 4. Defense Information Network (DISN) ARCHITECTURE. - DISA, Center for Systems Engineering. Version 1.2c, April 1998. 5. Signal і полягає наукова новизна і відмінність від відомих робіт.

Подальшими завданнями дослідження $є$ визначення факторів, що впливають на інші показники якості С3, та встановлення функціональних залежностей значення цих показників від керованих змінних, а також проведення експертного опитування провідних фахівців в галузі організації зв'язку та кількісна оцінка значень вагових коефіцієнтів окремих показників якості С3.

Реалізація вказаних завдань дозволяє отримати комплексну оцінку ефективності С3.

battalion recognized for outstanding support, The Maple Leaf, 28 September 2007, Vol. 10, №. 6. 6. Зайцева Е.Н. Исследования надежности информационных систем / Е.Н. Зайцева // Електросвязь. - 2003. - № 6. - С. 37-39. 7. Харыбин А.В. О подходе к решению задачи выбора методологии оценки структурной надежности и живучести информационных систем критического применения / А.В. Харыбин, О.Н. Одарущенко // Радіоелектронні і комп'ютерні системи. - Х. : НАУ "XАI". - 2006. - № 6(18). - С. 61-70. 8. Головань С.М. Основи надійності інформаційних систем / С.М. Головань, О.В. Корнейко, О.С. Петров, В.О. Хорошко, Л.М. Щербак. Луганськ : Вид-во “Наулідж”, 2012. - 335 с. 9. Волочій Б.Ю. 
Системотехнічне проектування телекомунікаційних мереж / Б.Ю. Волочій, Л.Д. Озіровський. - Львів : Вид-во Львівська політехніка, 2012. - 128 с. 10. Гнатюк С.Є. Показники надійності систем зв'язку / С.Є. Гнатюк, Л.М. Сакович // Зв'язок. - 2013. - № 5. - C. 8-12. 11. Yanliang Li, Rui Kang, Lin Ma, Lei Li. Application and improvement study on FMEA in the process of military equipment maintenance. 9th International Conference on Reliability, Maintainability and Safety, 12-15 June 2011, Guiyang, China: Proc. IEEE, 2011, Vol. I, II, pp. 803-810. DOI: http://dx.doi.org/10.1109/ICRMS.2011.5979402. 12. Robert Thomson, John Lynn. The benefits of using head mounted displays and wearable computers in a military maintenance environment. 2010 International Conference on Education and Management Technology (ICEMT), 2-4 November 2010, Cairo, Egypt: Proc. IEEE, 2010, pp. 560-564. - DOI: http://dx.doi.org/10.1109/ICEMT.2010.5657592. 13. Qiao Ma, Guibo Yu, Lijun Cao, Jinhui Zhao, Bing Feng. Decision-making model for ranking battlefield damaged equipment repairs based on multi-criteria. 2013 International Conference on Quality, Reliability, Risk, Maintenance, and Safety Engineering (QR2MSE), 15-18 July 2013, Emeishan, Sichuan, China: Proc. IEEE, 2013, Vol. II, pp. 1942-1944. - DOI: http://dx.doi.org/10.1109/QR2MSE.2013. 6625959. 14. Haikuan Wang, Quan Shi, Fei Xiong, Kan Wang. The application of TOPSIS on sequencing decision-making in equipment battlefield repair. 2013 International Conference on Quality, Reliability, Risk, Maintenance, and Safety Engineering (QR2MSE), 15-18 July 2013, Emeishan, Sichuan, China: Proc. IEEE, 2013, Vol. II, pp. 1574-1578. - DOI: http://dx.doi.org/10.1109/QR2MSE.2013.6625876. 15. Chunliang Chen, Wenhua Shi, Shixin ZhangThe key operation ascertaining of armored equipment parts batch-repair progress for quality monitoring based on FCE. 2013 International Conference on
Quality, Reliability, Risk, Maintenance, and Safety Engineering (QR2MSE), 15-18 July 2013, Emeishan, Sichuan, China: Proc. IEEE, 2013. Vol. II, pp. 1542-1545. - DOI: http://dx.doi.org/10.1109/QR2MSE.2013.6625867. 16. Lenkov S.V, Zubarev V.V., Salimov R.M., Protsenko V.A. "Formalization of process of carrving out of repair of components of radioelectronic equipment", Visnik Cherkaskogo derjavnogo tehnologichnogo universitetu, pp. 20-22, 2009. 17. UddE. Application of Fiber Optic Smart Structures // Opt. and Photon News. - 1996. Vol. 7, № 5. - P. 17-22. 18. Senior J. M. Moss S.E., Cusworth S.D. Multiplexing Techniques for Noninterferometric Optical Point-Sensor Networks // Fiber and Integr. Opt. 1998. - Vol. 17, № 1. - Р. 3-20. 19. Надійність техніки. Терміни та визначення : ДСТУ 2860-94. - [Чинний від 1995-01-01]. - К. : Держстандарт України, 1995. - 90 с. (Національний стандарт України). 20. Поповский В.В. Методы априорной оценки сетевой надежности / В.В. Поповский, В.С. Волотка // Радиотехника. - Харьков : ХНУР, 2014. - Вип. № 178. - С. 20-23. 21. Рижаков В.А. Кількісне оцінювання структурної надійності систем зв'язку / В.А. Рижаков, Л.М. Сакович // Зв'язок. - 2004. - № 4. - С. 53-57. 22. Миночкин А.И. Управление топологией мобильной радиосети / А.И. Миночкин, В.А. Романюк // Зв'язок. - 2003. № 2. - С. 28-33. 23. Вентцель Е.С. Теория вероятностей. - М.: Высшая школа., 2002. - 275 с. 24. Сакович Л.Н. Выбор средств измерений для технического обслуживания и текущего ремонта оборудования систем защиты информации / Л.Н. Сакович, В.А. Рыжаков, В.П. Павлов // Правове, нормативне та метрологічне забезпечення систем захисту інформації в Украіні. - К. : НТУУ “КПІ”, 2003. - Вип. № 7. C. 77-85.

\title{
КОМПЛЕКСНОСТЬ ПОДХОДА К ОЦЕНИВАНИЮ ЭФЕКТИВНОСТИ ФУНКЦИОНИРОВАНИЯ СИСТЕМЫ СВЯЗИ ПО СООТВЕТСТВУЮЩИМ ПОКАЗАТЕЛЯМ КАЧЕСТВА
}

\author{
Лев Николаевич Сакович (канд. техн. наук, доцент) ${ }^{1}$ \\ Вадим Петрович Романенко (канд. техн. наук) \\ Сергей Свгеньевич Гнатюк (канд. техн. наук) \\ Игорь Юрьевич Розум (канд. військ, наук, стариий научний сотрудник)
}

\section{${ }^{1}$ Национальний техничний университет Украины “Киевский политехнический институт имени Игоря Сикорского”, Киев, Украина \\ ${ }^{2}$ Национальний университет обороны Украины имени Ивана Черняховского, Киев, Украина}

Повышение эфективности функционирования систем связи в современых условиях их розвитие есть одной из актуальных научно-практических проблем. Особое внимание в решении этой проблемы уделяется вопросу количественной оиенки эфективности функиионирования определённых систем, причём не по отдельными показателям, а комплексно с учётом влияния всех показателей качества на результат применения системь по назначению. Публикация имеет изель формализаиии процесса комплексной оценки ефективности системи связи и показать на примере соблюдение требований по надёжности и готовности возможности упорядочить действия по её оченке с расчётом вероятностных показателей качества.

Оценка эфективности системы связи - многокритериальная задача опредиления реального состояния различных составляющих качества её функционирования. Предложеная формализация комплексной оченки ефективности с учётом влияния на её значения отдельных показателей качества. Научная новизна роботы состоит в количественной оценке значения вероятностных показателей отдельных состовляющих и комплексной оценки качества функиионирования системь связи в ияелом. Полученые результати циелесообразно использовать как во время оценки ефективности существующих, так и при обоснованому вибору варианта розвития перспективных систем связи.

Ключевые слова: система связи, комплексная оценка ефективности функционирования системы

\section{A COMPLEXITY OF GOING IS NEAR EVALUATION OF EFFICIENCY OF FUNCTIONING THE COMMUNICATION NETWORKS ARE ON CORRESPONDING INDEXES OF QUALITY}

\author{
Lev Nikolayevich Sakovich (Candidate of Technical Sciences, Associate Professor) ${ }^{1}$ \\ Vadim Petrovich Romanenko (Candidate of Technical Sciences) ${ }^{1}$ \\ Sergey Evgeniyevich Gnatyuk (Candidate of Technical Sciences) ${ }^{1}$ \\ Igor Yuriyevich Rozum (Candidate of Military Sciences, Senior science employer) ${ }^{2}$
}




\section{${ }^{1}$ National Technical University of Ukraine the "Kyiv polytechnic institute of the name of Igor Sikorsky", Kyiv, Ukraine \\ ${ }^{2 .}$ National Defence University of Ukraine named after Ivan Cherniakhovsky, Kyiv, Ukraine}

Improving the efficiency of communication systems in the modern conditions of their development is one of the most urgent scientific and practical problems. Particular attention is paid to the problem of quantifying the effectiveness of the functioning of these systems, and not on individual indicators, but in a complex way, taking into account the influence of all indicators of quality on the result of the system's intended use. The purpose of the publication is to formalize the process of comprehensive assessment of the effectiveness of the communication system and to demonstrate, by way of example, the observance of the requirements for reliability and readiness, the opportunity to streamline its evaluation activities with the calculation of probabilistic quality indicators.

Evaluation of the efficiency of the communication system is a multi-criteria problem of determining the real state of various components of the quality of its functioning. The formalization of the complex estimation of efficiency is proposed, taking into account the influence on its value of separate quality indicators. Scientific novelty of the work consists in quantitative estimation of the value of the probabilistic indices of individual components and a comprehensive assessment of the quality of the functioning of the communication system in general. The results obtained should be used both in assessing the effectiveness of existing and well-founded choices for the development of promising communication systems.

Keywords: communication system, complex evaluation of the functioning of the system system

\section{References}

1. Oleynik V.F. Base teori of Communications. - Kiev: Techniques, 2000. - 152 c. 2. Edward Golan, Adam Kraśniewski, Janusz Romanik, Paweł Skarżyński, Robert Urban, "Experimental Performance Evaluationof the Narrowband VHF Tactical IP Radioin Test-Bed Environment", Military Communications and Information Technology: A Trusted Cooperation Enabler, vol. 2, pp. 99-106, 2012. 3. United States. Joint Chiefs of Staff, Defense Technical Information Center (DTIC). Joint Publication 6-0: Joint Communications System (2015, June 10). [Online]. Available: ttp:// www.dtic.mil/doctrine/new pubs/jp6 0.pdf. 4. Defense Information Network (DISN) ARCHITECTURE. - DISA, Center for Systems Engineering. Version 1.2c, April 1998. 5. Signal battalion recognized for outstanding support, The Maple Leaf, 28 September 2007, Vol. 10, No. 6. 6. Zayceva E.M. Researches of reliability of the informative systems / E.M. Zayceva // Electro Communications. 2003. - № 6. - C. 37-39. 7. Habarin A.V. About going near the decision of task of choice of methodology. / A.V. Habarin, O.M. Odaruschenko // Radioelectronic end Computer System. - Harkiv: NAU "HAI". - 2006. - № 6 (18). - C. 61-70. 8. Goloman S.M. Base realiability Information System / S.M. Goloman, O.V. Korneyko, O.S. Petrov, V.O. Horoshko, L.M. Scherbak. - Lugansk: "Naulidg", 2012. - 335c. 9. Volochiy B.Yu. System engineering design of telecommunication networks / B.Yu. Volochiy, L.D. Ozirovskiy. - Lvov: Lvovska politehnic, 2012. - 128 c. 10. Gnatyuk S.E. Показники reliability Sistem of Communications / S.E. Gnatyuk, L.N. Sakovich // Communications. - 2013. - № 5. - C. 8 12. 11. Yanliang Li, Rui Kang, Lin Ma, Lei Li. Application and improvement study on FMEA in the process of military equipment maintenance. 9th International Conference on Reliability, Maintainability and Safety, 12-15 June 2011, Guivang, China: Proc. IEEE, 2011, Vol. I, II, pp. 803-810. - DOI: http://dx.doi.org/ 10.1109/ICRMS.2011.5979402. 12. Robert Thomson, John Lynn. The benefits of using head mounted displays and wearable computers in a military maintenance environment. 2010 International Conference on Education and Management Technology (ICEMT), 24 November 2010, Cairo, Egypt: Proc. IEEE, 2010, pp. 560-564. DOI: http://dx.doi.org/10.1109/ICEMT.2010.5657592. 13. Qiao Ma, Guibo Yu, Lijun Cao, Jinhui Zhao, Bing Feng. Decision-making model for ranking battlefield damaged equipment repairs based on multi-criteria. 2013 International Conference on Quality, Reliability, Risk, Maintenance, and Safety Engineering (QR2MSE), 15-18 July
2013, Emeishan, Sichuan, China: Proc. IEEE, 2013, Vol. II, pp. 1942-1944. - DOI: http://dx.doi.org/10.1109/QR2MSE.2013. 6625959. 14. Haikuan Wang, Quan Shi, Fei Xiong, Kan Wang. The application of TOPSIS on sequencing decision-making in equipment battlefield repair. 2013 International Conference on Quality, Reliability, Risk, Maintenance, and Safety Engineering (QR2MSE), 15-18 July 2013, Emeishan, Sichuan, China: Proc. IEEE, 2013, Vol. II, pp. 1574-1578. - DOI: http://dx.doi.org/10.1109/QR2MSE. 2013.6625876. 15. Chunliang Chen, Wenhua Shi, Shixin ZhangThe key operation ascertaining of armored equipment parts batch-repair progress for quality monitoring based on FCE. 2013 International Conference on Quality, Reliability, Risk, Maintenance, and Safety Engineering (QR2MSE), 15-18 July 2013, Emeishan, Sichuan, China: Proc. IEEE, 2013. Vol. II, pp. 1542-1545. - DOI: http: //dx.doi.org/10.1109/QR2MSE.2013. 6625867. 16. Lenkov S.V, Zubarev V.V., Salimov R.M., Protsenko V.A. "Formalization of process of carrying out of repair of components of radio-electronic equipment", Visnik Cherkaskogo derjavnogo tehnologichnogo universitetu, pp. 20-22, 2009. 17. UddE. Application of Fiber Optic Smart Structures // Opt. and Photon News. - 1996. Vol. 7, № 5. - P. 17-22. 18. Senior J. M. Moss S.E., Cusworth S.D. Multiplexing Techniques for Noninterferometric Optical Point-Sensor Networks // Fiber and Integr. Opt. 1998. - Vol. 17, № 1. - P. 3-20. 19. Reliability Indicators Reliable Terms and definitions: DSTU 286094. - [Effective from 1 January 1995-01-01]. - K.: Gosstandart of Ukraine, 1995. - 90 p. - (National Standard of Ukraine). 20. Popovskiy V.V. Methods of a priori assessment of network reliability / V.V.Popovskiy, V.S. Volotka // Radiotechniques. Harkov: HNUR, 2014. - Вип. № 178. - С. 20-23. 21. Rizchakov V.A. Quantitative assessment of structural reliability Sistem of Communications / V.A. Rizchakov, L.N. Sakovich // Communications. - 2004. - № 4. - C. 53-57. 22. Minochkin A.I. The management of the topology of the mobile radio network / A.I. Minochkin, V.A. Romanyuk // Communications. - 2003. - № 2. - C. 28-33. 23. Ventcel E.S. The theory of probabilities. - M.: Higher school., 2002. - 275 c. 24. Sakovich L.N. Choice of measuring instruments for maintenance and current repair of equipment for information security systems / L.N. Sakovich, V.A. Rizchakov, V.P. Pavlov // Legal, normative and metrological provision of information security systems in Ukraine. $-\mathrm{K}$ : NTUU “KPI", 2003. - V. № 7. - C. 77-85. 